\title{
UNIAXIAL COMPRESSION TEST OF BULK SOYBEANS UNDER DIFFERENT PRE-TREATMENT TEMPERATURES
}

\author{
Hao Kit Ng, Abraham Kabutey, Alfadhl Yahya Khaled, David Herak \\ Czech University of Life Sciences Prague, Czech Republic \\ ng.hao_23808@utp.edu.my, kabutey@tf.czu.cz, f_yahya87@hotmail.com, herak@tt.czu.cz
}

\begin{abstract}
The study aimed at exploring the effects of different pre-treatment temperatures on bulk soybeans under uniaxial compression test. The initial pressing height of the samples was measured at $40 \mathrm{~mm}$ using a pressing vessel of diameter $60 \mathrm{~mm}$ with a plunger. The samples were pre-treated at temperatures from 45 to $-36^{\circ} \mathrm{C}$, all at a constant time of 30 minutes. Sample laboratory temperature of $25{ }^{\circ} \mathrm{C}$ served as the control. The dependencies between the force and deformation curves were recorded at a maximum force of $160 \mathrm{kN}$ and a speed of $5 \mathrm{~mm}$ min-1. Parameters calculated were mass of oil (g), oil yield (\%), volume oil (l), oil expression efficiency (\%), energy (J) and volume oil energy $\left(\mathrm{kJ} \cdot l^{-1}\right)$. The ANOVA results showed that deformation was not significant $(P$-value $>0.05)$ with temperature. Energy, oil expression efficiency and volume oil energy were significant $(P$-value $<0.05)$ with high coefficients of determination (R2) between 95 and $97 \%$. The study observed the optimum volume oil energy of $96.21 \pm 10.78 \mathrm{~kJ} \cdot 1^{-1}$ at $75{ }^{\circ} \mathrm{C}$ compared to $25{ }^{\circ} \mathrm{C}$ of $128.65 \pm 6.42 \mathrm{~kJ} \cdot 1^{-1}$ and $-2{ }^{\circ} \mathrm{C}$ of $195.54 \pm 18.35 \mathrm{~kJ} \cdot \mathrm{l}^{-1}$.
\end{abstract}

Keywords: soybeans, pretreatment, pressing, oil, energy.

\section{Introduction}

In the global oilseed production 2019/2020, soybeans accounted for 337.5 million metric tons compared to copra, cottonseed, palm kernel, peanuts, apeseed and sunflower seed, although the leading vegetable oil worldwide is palm oil [1]. Soybean oil is one of the most widely used industrial bio-based materials [2;3]. Brazil is currently the world's largest exporter of soybeans, while China is the largest importer, accounting for over $60 \%$ of the world's total exports [4-7], as well as the highest consumption of soybean oil worldwide [6]. Soybean is also a major protein source of animal feed [8]. Both the direct and indirect demands on soybeans thus contribute to the enormous consumption all over the world [5;8]. Oil extraction involves various preliminary operations, such as grinding, drying and cleaning. However, the total amount of extracted oil thus depends greatly on pressure, temperature, pressing time, moisture content and particle size of the oil-bearing material $[9 ; 10]$. Mechanical expression of oil in both linear (uniaxial compression) and non-linear (hydraulic and screw presses) requires the application of pressure with the corresponding speed to force the oil out of the oil-bearing material $[11 ; 12]$. Uniaxial and screw press are commonly used methods for oil expression in a small-medium scale production $[11 ; 13-15]$ compared to large scale production, where advanced techniques and green solvents, such as microwave-assisted and pressurized liquid extractions are used [16; 17].

The present study considered the uniaxial approach, where the material to be pressed is loaded into a pressing chamber with holes at the bottom that allow the oil to escape while the seedcake is retained. Here, the piston applies the desired compressive pressure. In this process, the mechanical properties such as force, deformation and toughness are important for designing oil expression equipment with maximum efficiency in the small-medium scale production, and to achieve this purpose, the oil processing factors need to be understood fully under the uniaxial compression process [18-20].

The study, therefore, evaluated the effects of heating and freezing pre-treatment temperatures on deformation, oil yield, oil expression efficiency, energy and volume oil energy of bulk soybeans under uniaxial compression loading.

\section{Materials and methods}

Bulk soybeans were purchased from the Supermarket in Prague, Czech Republic. The oil content of $11.36 \%$ was determined using a Soxhlet extraction method $[21 ; 22]$. The samples were measured at a pressing height of $40 \mathrm{~mm}$ using the vessel diameter of $60 \mathrm{~mm}$ and a plunger [23], and thereafter pretreated at temperatures between $45^{\circ} \mathrm{C}$ to $-36{ }^{\circ} \mathrm{C}$. The pre-treated samples were compressed at a 
maximum force of $160 \mathrm{kN}$ and speed of $5 \mathrm{~mm} \cdot \mathrm{min}^{-1}$ using the universal compression-testing machine (Tempos, ZDM 50, Czech Republic) [24]. The force-deformation curve (Figure 1) data were further processed for the calculation of the energy, which is characterized by the area under the curve [20;25]. Compression parameters, namely, mass of oil (g), oil yield (\%), volume oil (L), oil expression efficiency $(\%)$, energy $(\mathrm{J})$ and volume oil energy $\left(\mathrm{kJ} \cdot \mathrm{l}^{-1}\right)$ were calculated $[14 ; 26]$ and statistically analysed using the Statistica software [27] by employing One-Way ANOVA and Correlation techniques.
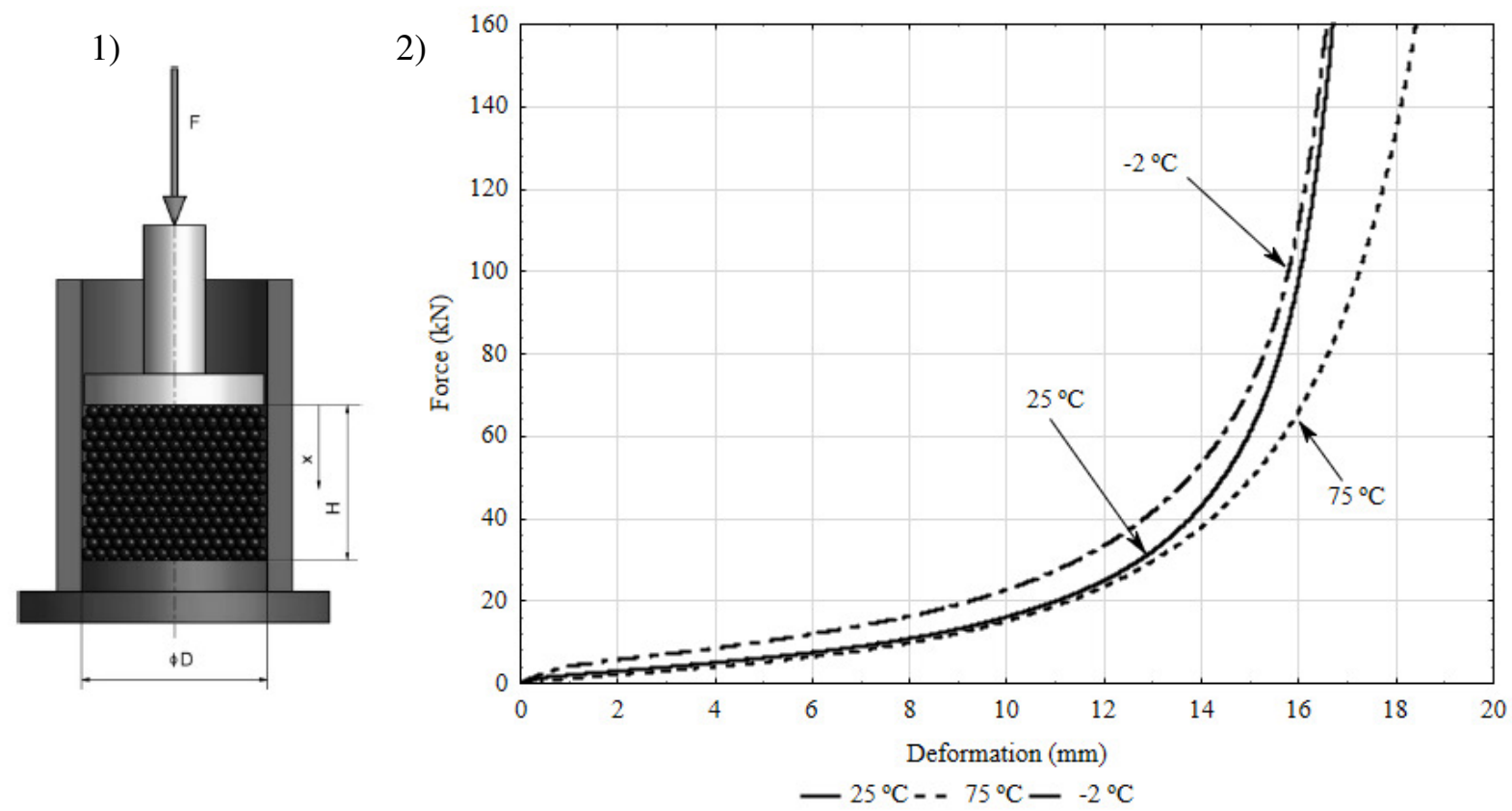

Fig. 1. Compression test of bulk soybeans: 1 - vessel diameter of $60 \mathrm{~mm}$ with a plunger ( $F$ - Force, $\mathrm{kN}$; $\mathrm{x}$ - deformation, $\mathrm{mm} ; \mathrm{H}$ - pressing height, $\mathrm{mm}$; [23]); 2 - force-deformation curves at different temperatures $\left(-22,-36,45\right.$ and $60{ }^{\circ} \mathrm{C}$ followed similar trends)

\section{Results and discussion}

The results of the provisional study are given in Tables 1 to 4 and Figures 1 to 4 . The mass of oil (g), oil yield (\%) and the volume oil (l) decreased from $-36{ }^{\circ} \mathrm{C}$ to $-2{ }^{\circ} \mathrm{C}$ and then increased from $25{ }^{\circ} \mathrm{C}$ until $75^{\circ} \mathrm{C}$ (Table 1). In other words, a decrease in the freezing temperatures from $-2{ }^{\circ} \mathrm{C}$ to $-36^{\circ} \mathrm{C}$ and an increase in the heating temperatures from $45^{\circ} \mathrm{C}$ to $75^{\circ} \mathrm{C}$ significantly $(P$-value $<0.05)$ increased the mass of oil, oil yield and the volume oil with high coefficients of determination $\left(\mathrm{R}^{2}\right)$ of approximately $97 \%$ based on the ANOVA results. The control $\left(25^{\circ} \mathrm{C}\right)$ showed almost similar values to that of $45^{\circ} \mathrm{C}$ heating temperature.

Table 1

Mass of oil, oil yield and volume oil of bulk soybeans

\begin{tabular}{|c|c|c|c|}
\hline $\begin{array}{c}\text { Temperature, } \\
{ }^{\mathbf{C}} \mathbf{C}\end{array}$ & $\begin{array}{c}* * \text { Mass of } \\
\text { oil, } \mathbf{g}\end{array}$ & $\begin{array}{c}\text { Oil yield, } \\
\mathbf{\%}\end{array}$ & $\begin{array}{c}* * \text { Volume oil, } \\
\mathbf{x ~ 1 0} \mathbf{~}^{-3} \mathbf{l}\end{array}$ \\
\hline$* 25$ & $2.94 \pm 0.07$ & $3.63 \pm 0.09$ & $3.21 \pm 0.08$ \\
\hline 45 & $3.00 \pm 0.16$ & $3.65 \pm 0.19$ & $3.27 \pm 0.17$ \\
\hline 60 & $4.46 \pm 0.26$ & $5.41 \pm 0.32$ & $4.86 \pm 0.29$ \\
\hline 75 & $4.94 \pm 0.45$ & $6.01 \pm 0.55$ & $5.39 \pm 0.49$ \\
\hline-2 & $2.31 \pm 0.11$ & $2.86 \pm 0.13$ & $2.52 \pm 0.12$ \\
\hline-22 & $2.38 \pm 0.31$ & $2.94 \pm 0.39$ & $2.60 \pm 0.34$ \\
\hline-36 & $2.65 \pm 0.08$ & $3.28 \pm 0.11$ & $2.89 \pm 0.09$ \\
\hline
\end{tabular}

* Control (Laboratory temperature);

** Density of oil: $917 \mathrm{~g} \cdot \mathrm{l}^{-1}$ 
Deformation (mm), oil expression efficiency (\%), energy (J) and energy volume oil $\left(\mathrm{kJ} \cdot \mathrm{l}^{-1}\right)$ of soybeans are presented in Table 2. The deformation values showed both decreasing and increasing trends. Oil expression efficiency increased at decreasing temperatures from $-2{ }^{\circ} \mathrm{C}$ to $-36{ }^{\circ} \mathrm{C}$, as well as heating temperatures from $45^{\circ} \mathrm{C}$ to $75^{\circ} \mathrm{C}$. Whereas energy increased at decreasing temperatures, it decreased at heating temperatures. This meant that soybeans harden at freezing temperatures, but soften at heating temperatures, hence, higher output oil. Energy volume oil was noticed to be higher at $-22{ }^{\circ} \mathrm{C}$ followed by $-36{ }^{\circ} \mathrm{C}$ and the lowest at $-2{ }^{\circ} \mathrm{C}$. However, $-2{ }^{\circ} \mathrm{C}$ showed much higher value than the control of $25^{\circ} \mathrm{C}$, indicating that it is not economically sustainable to freeze soybeans before oil extraction.

On the other hand, increased heating temperatures decreased the energy volume oil suggesting an economically sound way for obtaining maximum oil recovery. The results were statistically significant $(P$-value $<0.05)$, except deformation, which indicated non-significant $(P$-value $<0.05)$ (Table 3$)$. Generally, deformation and energy did not correlate $(P$-value $<0.05)$ with temperature, whereas oil expression efficiency and energy volume oil correlated with temperature $(P$-value $<0.05)$ (Table 4$)$.

The effect of temperature on energy, volume oil energy and oil expression efficiency is graphically shown in Fig. 2 and 3. The normal probability plot of energy volume oil, for instance, is presented in Fig. 4, for assessing the normal distribution of the data.

Table 2

Deformation, oil expression efficiency, energy and energy volume oil of bulk soybeans

\begin{tabular}{|c|c|c|c|c|}
\hline $\begin{array}{c}\text { Temperature, } \\
{ }^{\mathbf{0}} \mathbf{C}\end{array}$ & $\begin{array}{c}\text { Deformation, } \\
\mathbf{m m}\end{array}$ & $\begin{array}{c}\text { Oil } \\
\text { expression } \\
\text { efficiency, \% }\end{array}$ & $\begin{array}{c}\text { Energy, } \\
\mathbf{J}\end{array}$ & $\begin{array}{c}\text { Energy } \\
\text { volume oil, kJ· } \mathbf{I}^{-1}\end{array}$ \\
\hline$* 25$ & $17.49 \pm 1.12$ & $31.99 \pm 0.77$ & $412.70 \pm 30.50$ & $128.65 \pm 6.42$ \\
\hline 45 & $18.32 \pm 0.18$ & $32.11 \pm 1.68$ & $614.57 \pm 9.50$ & $188.03 \pm 6.85$ \\
\hline 60 & $19.42 \pm 0.27$ & $47.67 \pm 2.81$ & $561.43 \pm 7.14$ & $115.81 \pm 8.27$ \\
\hline 75 & $17.84 \pm 0.81$ & $52.92 \pm 4.81$ & $516.20 \pm 11.41$ & $96.21 \pm 10.78$ \\
\hline-2 & $18.83 \pm 3.21$ & $25.19 \pm 1.14$ & $492.58 \pm 23.70$ & $195.54 \pm 18.35$ \\
\hline-22 & $17.51 \pm 0.28$ & $25.90 \pm 3.41$ & $529.06 \pm 3.24$ & $205.52 \pm 25.62$ \\
\hline-36 & $18.01 \pm 0.36$ & $28.84 \pm 0.94$ & $583.61 \pm 10.85$ & $202.11 \pm 10.23$ \\
\hline
\end{tabular}

* Control, laboratory temperature

Table 3

ANOVA test of sum of squares whole model

\begin{tabular}{|l|c|c|c|}
\hline \multicolumn{1}{|c|}{$\begin{array}{c}\text { Dependent } \\
\text { variables }\end{array}$} & $\boldsymbol{R}^{\mathbf{2}}$ & $\boldsymbol{F}$ value & $\boldsymbol{P}$-value \\
\hline Deformation, mm & 0.329 & 0.572 & 0.743 \\
\hline Oil expression efficiency, \% & 0.967 & 34.652 & 0.000 \\
\hline Energy, J & 0.965 & 32.520 & 0.000 \\
\hline Energy volume oil, $\mathrm{kJ} \cdot \mathrm{l}^{-1}$ & 0.949 & 21.932 & 0.000 \\
\hline
\end{tabular}

$R^{2}$ : coefficient of determination;

$F$ value: compares a pair of models;

Table 4

Correlation results of bulk soybean compression parameters

\begin{tabular}{|c|c|c|c|c|}
\hline Variable & $\begin{array}{c}\text { Deformation, } \\
\text { mm } \\
\end{array}$ & $\begin{array}{c}\text { Oil expression } \\
\text { efficiency, \% }\end{array}$ & $\begin{array}{c}\text { Energy, } \\
\mathrm{J}\end{array}$ & 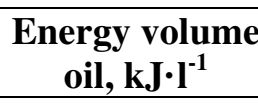 \\
\hline Temperature, ${ }^{\circ} \mathrm{C}$ & 0.173 & 0.836 & -0.007 & -0.815 \\
\hline$P$-value & 0.555 & 0.000 & 0.982 & 0.000 \\
\hline
\end{tabular}

$P$ value $<0.05:$ Significant;

$P$ value $>0.05$ : Non-significant 
Wilks lambda $=.00009, \mathrm{~F}(24,15.164)=8.4680, \mathrm{p}=.00004$

Vertical bars denote 0.95 confidence intervals

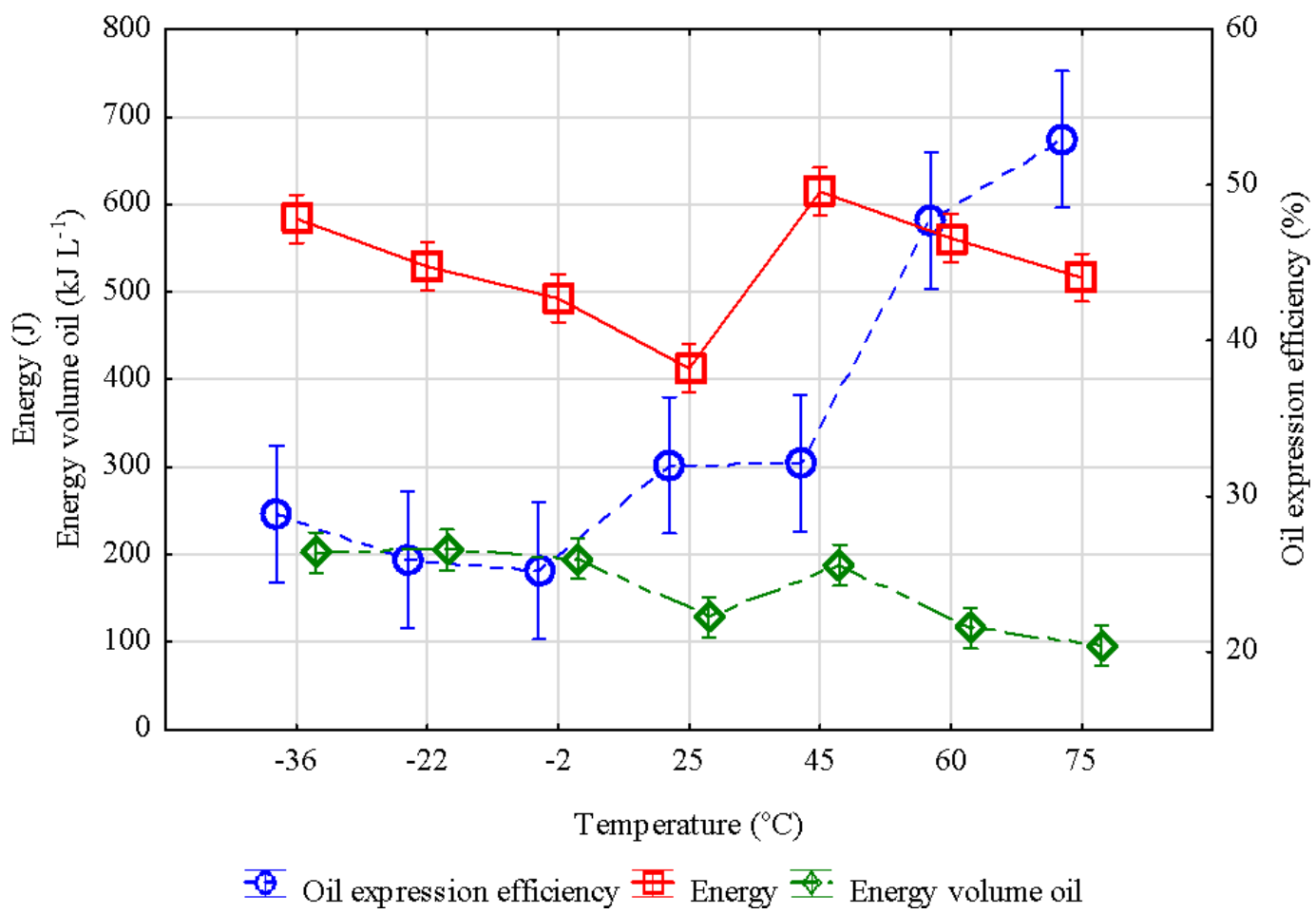

Fig. 2. Effect of temperature on energy, energy volume oil and oil expression efficiency Energy volume oil $\left(\mathrm{kJ} \mathrm{L}^{-1}\right)=180.73-0.9190 *$ T emperature $\left({ }^{\circ} \mathrm{C}\right)$ Correlation: $\mathrm{r}=-0.8145$

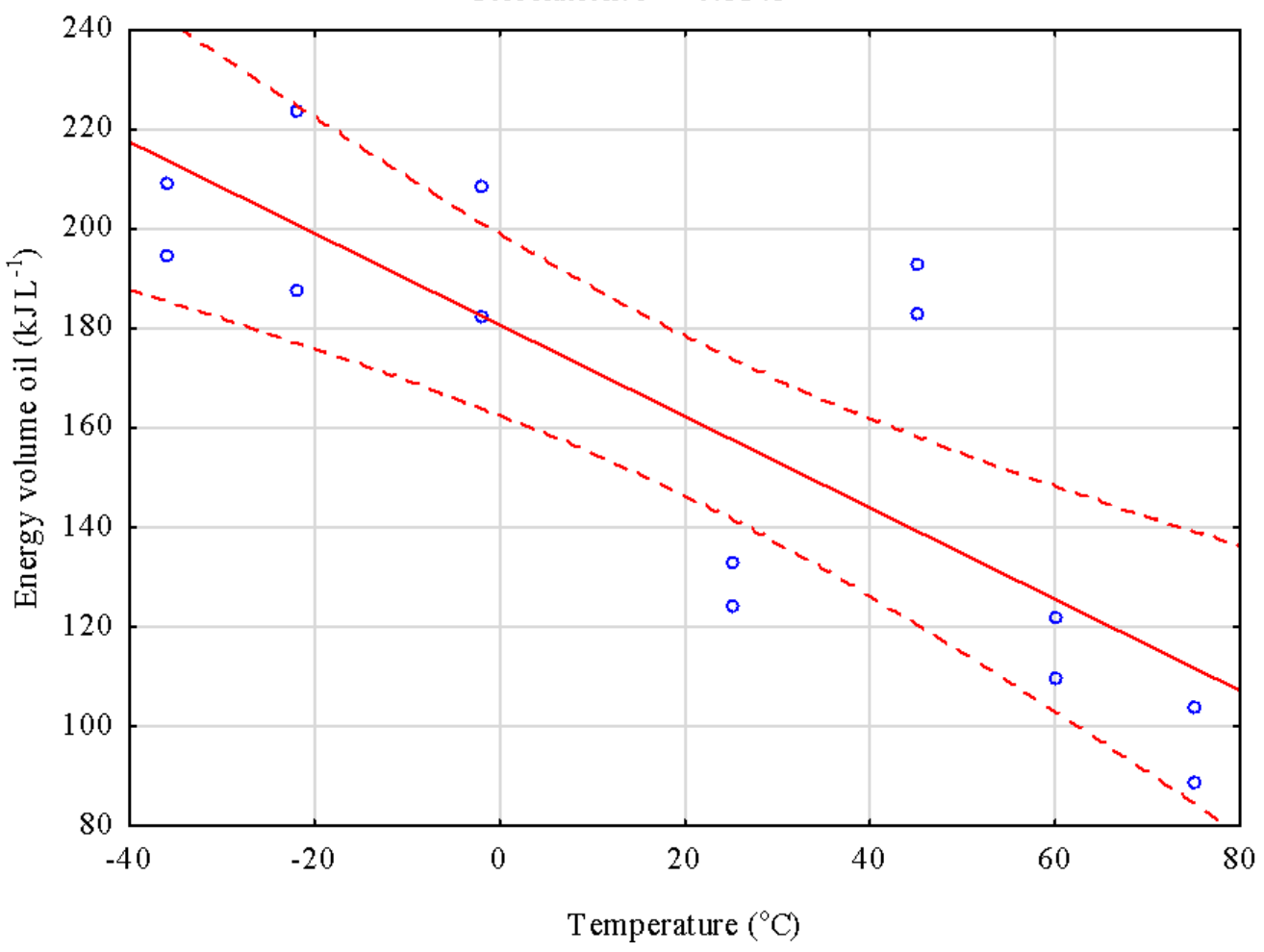

Fig. 3. Scatterplot of energy volume oil against temperature 


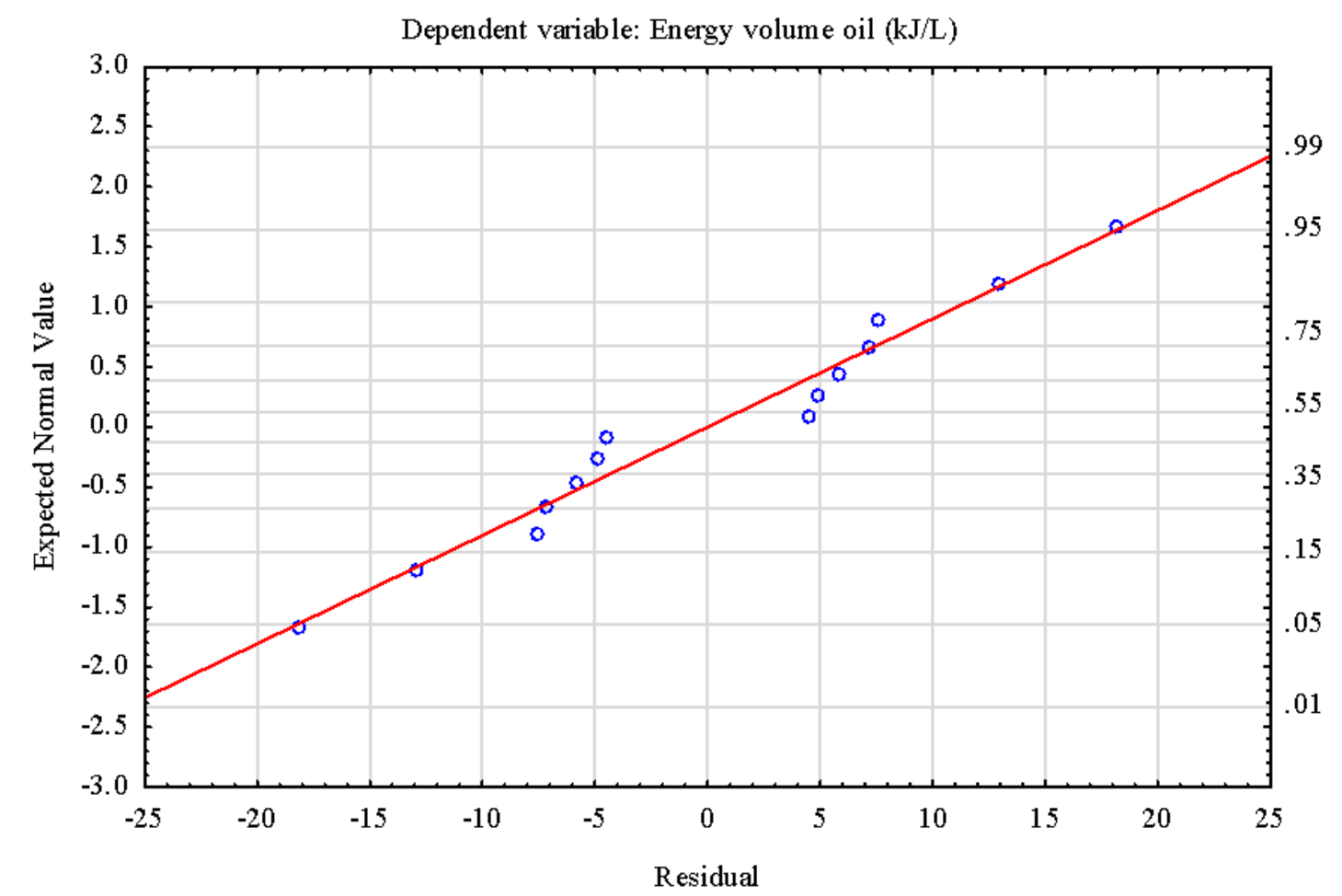

Fig. 4. Normal probability plot; raw residuals of energy volume oil $\left(\mathbf{k J} \cdot \mathbf{l}^{-1}\right)$

\section{Conclusions}

A provisional study result of soybean uniaxial compression test is presented.

1. Oil expression efficiency (\%) increased at the pre-treatment temperatures from $-2{ }^{\circ} \mathrm{C}$ to $-36{ }^{\circ} \mathrm{C}$ and $45^{\circ} \mathrm{C}$ to $75^{\circ} \mathrm{C}$. However, higher efficiency was achieved at $75^{\circ} \mathrm{C}$.

2. Energy $(\mathrm{J})$ increased at the pre-treatment temperatures from $-2{ }^{\circ} \mathrm{C}$ to $-36^{\circ} \mathrm{C}$, but decreased at 45 ${ }^{\circ} \mathrm{C}$ to $75^{\circ} \mathrm{C}$. This suggests that freezing hardens, while heating softens the beans.

3. Optimum volume oil energy of $96.21 \pm 10.78 \mathrm{~kJ} \cdot 1^{-1}$ was observed at the heating temperature of $75^{\circ} \mathrm{C}$ compared to the control $\left(25^{\circ} \mathrm{C}\right)$ and the freezing temperature $\left(-2{ }^{\circ} \mathrm{C}\right)$ values of $128.65 \pm 6.42 \mathrm{~kJ} \cdot 1^{-1}$ and $195.54 \pm 18.35 \mathrm{~kJ} \cdot \mathrm{l}^{-1}$ respectively.

4. This study will continue further by considering the chemical analysis of the oil for quality assessment after pre-treatment temperatures [21], as well as the application of a higher compression force, higher pressing height (volume of material) and bigger pressing vessels.

\section{Acknowledgement}

The study was supported by the Internal Grant Agency of the Faculty of Engineering, Department of Mechanical Engineering, Czech University of Life Sciences Prague, 2020:31130/1312/3114.

\section{References}

[1] Worldwide oilseed production in 2019/2020, by type. [online][11.02.2020] Available at: https://www.statista.com/statistics/267271/worldwide-oilseed-production-since2008/\#statisticContainer.

[2] Dong B., Yuan, Y., Luo J., Dong L., Liu R., Liu X. Acryloyl-group functionalized grapheme for enhancing thermal and mechanical properties of acylated epoxidized soybean oil UV-curable based coatings. Progress in Organic Coatings, vol. 118, 2018, pp. 57-65.

[3] Quiles-Carrillo L., Duart S., Montanes N., Torres-Giner S., Balart R. Enhancement of the mechanical and thermal properties of injection-molded polylactide parts by the addition of acrylated epoxidized soybean oil. Materials and Design, vol. 140, 2018, pp. 54-63.

[4] Santos J.F.S., Naval L.P. Spatial and temporal dynamics of water footprint for soybean production in areas of recent agricultural expansion of the Brazilian savannah (Cerrado). Journal of Cleaner Production, vol. 251(119482), 2020, pp. 1-13. 
[5] Wu F., Geng Y., Zhang Y., Ji C., Chen Y., Sun L., Xie W., Ali T., Fujita T. Assessing sustainability of soybean supply in China: Evidence from provincial production and trade data. Journal of Cleaner Production, vol. 244(119006), 2020, pp. 1-14.

[6] China: Oilseeds and Products Annual. USDA, 2018.

[7] Spera S.A., Galford M.T., Coe M.N., Mustard J.F. Land-use change affects water recycling in Brazil's last agricultural frontier. Global Change Biology, vol. 22, 2016, pp. 3405-3413.

[8] Kibar H., Ozturk T. Physical and mechanical properties of soybean. International Agrophysics, vol. 22, 2008, pp. 239-244.

[9] Sirisomboon P., Kitchaiya P. Physical properties of Jatropha curcas L. kernels after heat treatments. Biosystems Engineering, vol. 102, 2009, 244-250.

[10] Gutierrez L.F., Ratti C., Belkacerni K. Effects of drying method on the extraction yields and quality of oils from Quebec sea buckthorn (Hippophae rhamnoides L.) seeds and pulp. Food Chemistry, vol. 106(3), 2008, pp. 896-904.

[11] Munson-Mcgee S.H. D-optimal experimental designs for uniaxial expression. Journal of Food Process Engineering, vol. 37, 2014, 248-256.

[12] Ogunsina B.S., Owolarafe O.k., Olatunde G.A. Oil point pressure of cashew (Anacardium occidentale) kernels. International Agrophysics, vol. 22, 2008, 53-59.

[13] Mizera C., Herak D., Hrabe P., Kabutey A. Extraction of oil from rapeseed using duo screw press. Agronomy Research, vol. 16(S1), 2018, pp. 1118-1123.

[14] Divisova M., Herak D., Kabutey, A., Sleger V., Sigalingging R., Svatonova T. Deformation curve characteristics of rapeseeds and sunflower seeds under compression loading. Scientia Agriculturae Bohemica, vol. 45(3), 2014, pp. 180-186.

[15] Munson-Mcgee S.H. D-optimal experimental designs for uniaxial expression. Journal of Food Process Engineering, vol. 37, 2014, pp. 248-256.

[16] Castejon N., Luna P., Senorans F.J. Alternative oil extraction methods from Echium plantagineum L. seeds using advanced techniques and green solvents. Food Chemistry, vol. 244, 2018, 75-82.

[17] Conte R., Gullich L.M.D., Bilibo O., Zanella J.P., Carniel N., Priamo W.L. Pressurized liquid extraction and chemical characterization of safflower oil: a composition between methods. Food Chemistry, vol. 213, 2016, 425-430.

[18] Correa P.C., Resende O., Ribeiro D.M., Jaren C., Arazuri S. Resistance of edible beans to compression. Journal of Food Engineering, vol. 86, 2008, pp. 172-177.

[19] Lysiak G. Fracture toughness of pea: Weibull analysis. Journal of Food Engineering, vol. 83, 2007, pp. 436-443.

[20] Gupta R.K., Das S.K. Fracture resistance of sunflower seed and kernel to compressive loading. Journal of Food Engineering, vol. 46, 2000, pp. 1-8.

[21] Gurkan A.K.G., Kabutey A., Selv K.C., Hrabe P., Herak D., Frankova A. Investigation of heating and freezing pretreatments on mechanical, chemical and spectral properties of bulk sunflower seeds and oil. Processes, vol. 8(411), 2020, pp. 1-20.

[22] Niu L., Li J., Chen M.S., Xu Z.E. Determination of oil contents in Sachia inchi (Plukenetia volubilis) seeds at different developmental stages by two methods: Soxhlet extraction and timedomain nuclear magnetic resonance. Industrial Crops and Products, vol. 56, 2014, pp. 187-190.

[23] Herak D., Kabutey A., Divisova M., Simanjuntak S. Mathematical model of mechanical behaviour of Jatropha curcas L. seeds under compression loading. Biosystems Engineering, vol. 114, 2013, pp. 279-288.

[24]Demirel C., Gurdil G.A.K., Kabutey A., Wasserbauer M. Comparing energy demand of densified briquettes of ground and unground hazelnut husks under compression loading. IOP Conference Series, Earth and Environmental Science, vol. 260, 2019, pp. 1-5.

[25] Demirel C., Kabutey A., Herak D., Gurdil G.A.K. Numerical estimation of deformation energy of selected bulk oilseeds in compression loading. IOP Conference Series, Earth and Environmental Science, vol. 237, 2017, pp. 1-5.

[26] Deli S., Farah Masturah M., Tajul Aris Y., Wan Nadiah W.A. The effects of physical parameters of the screw press oil expeller on oil yield from Nigella sativa L. seeds. International Food Research Journal, vol. 18, 2011, pp. 1367-1373.

[27] StatSoft Inc. (1995). STATISTICA for Windows. Statsoft Inc.: Tulsa, OK, USA, 2013. 